\title{
Clinical characteristics and outcomes of patients with pediatric acute lymphoblastic leukemia after induction of chemotherapy: a pilot descriptive correlational study from Palestine
}

\author{
Ramzi Shawahna ${ }^{1,2^{*}}$, Sultan Mosleh ${ }^{3}$, Yahya Odeh ${ }^{4+}$, Rami Halawa $^{4 \dagger}$ and Majd Al-Ghoul ${ }^{4 \dagger}$
}

\begin{abstract}
Objective: Pediatric acute lymphoblastic leukemia (ALL) is the most prevalent type of cancer among children. This study was conducted to describe and correlate the clinical characteristics and outcomes of treatment of patients with pediatric ALL in the main referral hospital in Palestine.

Results: Complete data of 69 patients were included in this analysis. The majority (79.7\%) of the patients had B-ALL phenotype. After induction chemotherapy, remission was experienced by the vast majority of the patients and 5 (7.2\%) experienced relapses. Cytogenetics for patients with B-ALL phenotype indicated that 10 (18.2\%) patients had $\mathrm{t}(12,21)$ translocation, $5(9.1 \%)$ had hyperdiploidy, $4(7.3 \%)$ had $\mathrm{t}(1,19)$ translocation, and $2(3.6 \%)$ had $\mathrm{t}(9$, 22 ) translocation. The initial white blood cells ( $p$ value $<0.001$ ), absolute neutrophils ( $p$ value $=0.011$ ), and hemoglobin ( $p$ value $<0.001$ ) were significantly lower in patients with B-cell ALL. Platelet counts were significantly lower ( $p$ value $=0.012$ ) in patients with splenomegaly and those with bleeding symptoms ( $p$ value $=0.008$ ). Presence of palmar pollar was positively associated ( $p$ value $=0.035$ ) with T-cell ALL. Presence of hepatomegaly was positively associated ( $p$ value $<0.001$ ) with splenomegaly.
\end{abstract}

Keywords: Acute lymphoblastic leukemia, Induction chemotherapy, Treatment, Translocation, Palestine

\section{Introduction}

Cancer is the second most common cause of mortality among Palestinians in the West Bank and Gaza Strip [1]. In general, leukemias are the most common type of cancer among Palestinian children with an estimated incidence rate of 2.6 per 100,000 children $[1,2]$. Acute

\footnotetext{
*Correspondence: ramzi_shawahna@hotmail.com

†Yahya Odeh, Rami Halawa and Majd Al-Ghoul contributed equally to this work

${ }^{1}$ Department of Physiology, Pharmacology and Toxicology, Faculty of Medicine and Health Sciences, An-Najah National University, New Campus, Building: 19, Office: 1340, P.O. Box 7, Nablus, Palestine

Full list of author information is available at the end of the article
}

lymphoblastic leukemia (ALL) is the most diagnosed tumor in pediatric population and the most frequent cause of death from cancer before the age of 20 [3]. According to some estimates, more than $75 \%$ of pediatric leukemias are ALL. On annual basis, about 6000 ALL cases are diagnosed in the US, of those, about $50 \%$ are children and teenagers $[4,5]$.

In Palestine, cancer care is highly fragmented and a high percentage of patients receive treatment outside the country $[1,6]$. Currently, referral hospitals in which patients with pediatric ALL receive induction chemotherapy in Palestine are limited [1, 6]. Since its inception, An-Najah National Hospital has emerged as the

(c) The Author(s) 2021. This article is licensed under a Creative Commons Attribution 4.0 International License, which permits use, sharing, adaptation, distribution and reproduction in any medium or format, as long as you give appropriate credit to the original author(s) and the source, provide a link to the Creative Commons licence, and indicate if changes were made. The images or other third party material in this article are included in the article's Creative Commons licence, unless indicated otherwise in a credit line to the material. If material is not included in the article's Creative Commons licence and your intended use is not permitted by statutory regulation or exceeds the permitted use, you will need to obtain permission directly from the copyright holder. To view a copy of this licence, visit http://creativeco mmons.org/licenses/by/4.0/. The Creative Commons Public Domain Dedication waiver (http://creativecommons.org/publicdomain/ zero/1.0/) applies to the data made available in this article, unless otherwise stated in a credit line to the data. 
main referral hospital for pediatric ALL in Palestine. Description of the epidemiological and clinical characteristics of patients with ALL in different nations has received considerable attention [7]. The Middle East Childhood Cancer Alliance (MECCA) collected clinical and demographic data on children with ALL from 16 countries in the Middle East [8]. However, Palestinians were not included in MECCA's study. Currently, little is known on the epidemiological and clinical characteristics of patients with pediatric ALL among Palestinians [2]. Therefore, this pilot study was conducted to describe the clinical characteristics and outcomes of induction chemotherapy among patients with pediatric ALL in the main referral hospital in Palestine. The study also aimed to assess the associations between sociodemographic and clinical characteristics of the patients included in the study. The study provided insights into the clinical characteristics and outcomes of induction chemotherapy in Palestinian patients with pediatric ALL.

\section{Methods}

\section{Study participants}

Patients with pediatric ALL were included in this study. The inclusion criteria were: (a) patients who were 16 years old and younger, (b) admitted to the referral hospital with a diagnosis of pediatric ALL, and (c) received induction chemotherapy at the study site. With not restrict inclusion based on gender or admission dates. We excluded patients whose medical records were incomplete and those who received their induction chemotherapy outside the referral hospital. All patients with a diagnosis of pediatric ALL regardless of their gender or admission dates were screened against the inclusion and exclusion criteria.

\section{Study design, tools, and collection of data}

This present study was a single-center, retrospective, observational study. The study used a descriptive correlational approach. In this study, paper-based and electronic medical records of patients with pediatric ALL were reviewed by field researchers. A data collection form that was created for this study using Excel Spreadsheets (Microsoft Excel, Microsoft Inc, US) was used to extract the pertinent data relevant to sociodemographic, physical examination, daily progress, hematological, clinical, bone marrow biopsies, flow cytometry, and cytogenetics. The data collected for this study were informed by previous studies [8-10]. Data were collected from the time the patient was admitted until outcomes of induction became available. The outcomes of the induction were assessed based on bone marrow biopsies performed on days 19-21 after initiation of induction chemotherapy. In this study, the outcomes were classified as follows: (a) remission ( $<5 \%$ blast on bone marrow), (b) non-remission ( $\geq 5 \%$ blast on bone marrow), (c) relapse $(\geq 20 \%$ blast in bone marrow, any blasts in CNS or both, or (d) death of the patient during the first admission for the induction chemotherapy.

\section{Statistical analysis}

Data were entered into IBM SPSS for Windows v.21.0 (IBM Inc., Armonk, New York). Kolmogorov-Smirnov test was used to assess whether the data were normally distributed or not. Because the data were not normally distributed, the data were expressed using medians and their corresponding interquartile range (IQR). Categorical data were compared using Mann-Whitney $U$ test. Correlation was investigated using Spearman's rank correlation. Statistical significance was considered when the $\mathrm{p}$ value was $<0.05$.

\section{Results}

All medical records of patients who received induction chemotherapy at An-Najah National Hospital were reviewed. Complete records and laboratory reports were identified for a total of 69 patients. Patients with complete records and laboratory reports were included in the final analysis.

\section{Sociodemographic, clinical, and hematological variables of the study patients}

Cytogenetic studies for the B-ALL phenotype showed that $10(18.2 \%)$ patients had $\mathrm{t}(12,21)$ translocation, 5 (9.1\%) had hyperdiploidy, $4(7.3 \%)$ had $t(1,19)$ translocation, and $2(3.6 \%)$ had $t(9,22)$ translocation. Of all patients, 19 (34.5\%) did not have any of the previously mentioned abnormal cytogenetics. Detailed sociodemographic, clinical, and hematological variables of the patients are shown in Table 1.

\section{Association between the different sociodemographic and clinical variables of the study patients with their hematologic laboratory findings}

The median hemoglobin in patients who were 5 years of age and older (9.1 with an IQR of $2.5 \mathrm{~g} / \mathrm{dL}$ ) was significantly higher ( $\mathrm{p}$ value $=0.007$ ) than those who were younger than 5 years $(7.8$ with an IQR of $2.8 \mathrm{~g} / \mathrm{dL}$ ) (Table 2). The median platelet count in patients who did not have splenomegaly $(122,000$ with an IQR of 169,000$)$ was significantly higher ( $\mathrm{p}$ value $=0.012$ ) than those who had splenomegaly $(49,500$ with an IQR of 145,850$)$. The median platelet count for patients who did not have bleeding symptoms $(103,000$ with an IQR of 171,000$)$ was significantly higher ( $\mathrm{p}$ value $=0.008$ ) than those who had bleeding symptoms $(34,000$ with an IQR of 66,050$)$. The median hemoglobin for patients who had T-ALL (11.2 
Table 1 Sociodemographic, clinical, and hematological variables of the patients with pediatric ALL included in the study $(n=69)$

\begin{tabular}{|c|c|c|}
\hline Variable & $\mathrm{n}$ & $\%$ \\
\hline \multicolumn{3}{|l|}{ Age (years) } \\
\hline$<10$ & 26 & 37.7 \\
\hline$\geq 10$ & 43 & 62.3 \\
\hline \multicolumn{3}{|l|}{ Gender } \\
\hline Male & 42 & 60.9 \\
\hline Female & 27 & 39.1 \\
\hline \multicolumn{3}{|c|}{ Presence of abdominal pain } \\
\hline Yes & 22 & 31.9 \\
\hline No & 47 & 68.1 \\
\hline \multicolumn{3}{|l|}{ Presence of fever } \\
\hline Yes & 37 & 53.6 \\
\hline No & 32 & 46.4 \\
\hline \multicolumn{3}{|c|}{ Presence of bone pain } \\
\hline Yes & 30 & 43.5 \\
\hline No & 39 & 56.5 \\
\hline \multicolumn{3}{|l|}{ CNS status ${ }^{\mathrm{a}}$} \\
\hline CNS 1 & 66 & 95.7 \\
\hline CNS 2 & 1 & 1.4 \\
\hline CNS 3 & 2 & 2.9 \\
\hline \multicolumn{3}{|l|}{ Presence of pallor } \\
\hline Yes & 50 & 72.5 \\
\hline No & 19 & 27.5 \\
\hline \multicolumn{3}{|c|}{ Presence of anorexia } \\
\hline Yes & 9 & 13 \\
\hline No & 60 & 87 \\
\hline \multicolumn{3}{|c|}{ Presence of hepatomegaly ${ }^{\mathrm{b}}$} \\
\hline Yes & 34 & 49.3 \\
\hline No & 35 & 50.7 \\
\hline \multicolumn{3}{|c|}{ Presence of splenomegalyc } \\
\hline Yes & 34 & 49.3 \\
\hline No & 35 & 50.7 \\
\hline \multicolumn{3}{|c|}{ Presence of bleeding ${ }^{d}$} \\
\hline Yes & 15 & 21.7 \\
\hline No & 54 & 78.3 \\
\hline \multicolumn{3}{|c|}{ Immunophenotype } \\
\hline B-ALL & 55 & 79.7 \\
\hline T-ALL & 14 & 20.3 \\
\hline \multicolumn{3}{|c|}{ Cytogenetics for B-ALL } \\
\hline$t(12,21)$ & 10 & 18.2 \\
\hline Hyperdiploidy & 5 & 9.1 \\
\hline $\mathrm{t}(1,19)$ & 4 & 7.3 \\
\hline$t(9,22)$ & 2 & 3.6 \\
\hline Nil & 19 & 34.5 \\
\hline Missing & 15 & 27.3 \\
\hline \multicolumn{3}{|l|}{ Relapse $\mathrm{e}^{\mathrm{e}}$} \\
\hline Yes & 5 & 7.2 \\
\hline No & 64 & 92.8 \\
\hline \multicolumn{3}{|l|}{ Remission $^{f}$} \\
\hline Yes & 68 & 98.5 \\
\hline
\end{tabular}

Table 1 (continued)

\begin{tabular}{|c|c|c|}
\hline Variable & $\mathbf{n}$ & $\%$ \\
\hline No & 1 & 1.5 \\
\hline Hematological laboratory data at admission & Median & IQR \\
\hline Hemoglobin (g/dL) & 9.0 & 2.7 \\
\hline Platelet count (per mm³) & 80000 & 157000 \\
\hline Initial WBCs count (cells/mm³) & 7100 & 20600 \\
\hline Absolute neutrophils count (cells/mm³) & 1420 & 2030 \\
\hline \multicolumn{3}{|l|}{ IQR interquartile range, WBCs white blood cells } \\
\hline \multicolumn{3}{|c|}{$\begin{array}{l}\text { a } C N S 1: \text { WBC in } C S F<5 \text { without WBC blasts, CNS2: WBC in } C S F<5 \text { with WBC } \\
\text { blasts, CNS3: WBC in CSF }>5 \text { with WBC blasts }\end{array}$} \\
\hline \multicolumn{3}{|l|}{${ }^{\mathrm{b}}$ Hepatomegaly: palpable liver below the costal margin } \\
\hline \multicolumn{3}{|l|}{ 'Splenomegaly: palpable spleen } \\
\hline \multicolumn{3}{|c|}{$\begin{array}{l}\text { d Presence of bleeding symptoms like petechiae, epistaxis, bruising, gum } \\
\text { bleeding, blood in stool }\end{array}$} \\
\hline \multicolumn{3}{|c|}{$\begin{array}{l}\text { e Relapse: patient was in remission and developing any of the following: } 1 \text {. More } \\
\text { than } 20 \% \text { of blasts in bone marrow, or, } 2 \text {. CNS status } 2 \text { or } 3 \text {, or, } 3 \text {. Both } 1+2\end{array}$} \\
\hline \multicolumn{3}{|c|}{$\begin{array}{l}{ }^{f} \text { Remission: the percentage of blast cells in the bone marrow is less than } 5 \% \text { at } \\
\text { the end of induction of chemotherapy }\end{array}$} \\
\hline
\end{tabular}

with an IQR 2.8 ) was significantly higher ( $\mathrm{p}$ value $<0.001$ ) than those who had B-ALL (8.4 with an IQR of 2.5). The median initial WBCs count for patients who had T-ALL $(22,100$ with an IQR 35,550$)$ was significantly higher ( $p$ value $<0.001$ ) than those who had B-ALL ( 5000 with an IQR of 10,950). The median absolute neutrophil count for patients who had T-ALL (2670 with an IQR of 4595) was significantly higher ( $\mathrm{p}$ value $=0.011$ ) than those who had B-ALL (1050 with an IQR 1730).

\section{Correlation between sociodemographic and clinical characteristics of patients with pediatric ALL}

There was a positive correlation ( $\mathrm{p}$ value $=0.035$ ) between the presence of pallor at presentation and T-ALL immunophenotype. Again, there was a positive correlation ( $\mathrm{p}$ value $<0.001$ ) between the presence of hepatomegaly and the presence of splenomegaly (Table 3 ).

\section{Discussion}

This is the first description of hematological laboratory findings, signs and symptoms at presentation, immunophenotype, cytogenetics, and outcomes of induction chemotherapy for patients with pediatric ALL who received induction chemotherapy at the main referral hospital for pediatric ALL patients in Palestine. The study also established associations between hematological laboratory findings, sociodemographic, and clinical variables of the patients.

At presentation, the median hemoglobin concentration was 9.0 with an IQR of $2.7 \mathrm{~g} / \mathrm{dL}$. Hemoglobin levels reported in this study were comparable to those reported in a previous larger study in the Middle East [8] and other regional studies in Jordan [11] and Brazil 


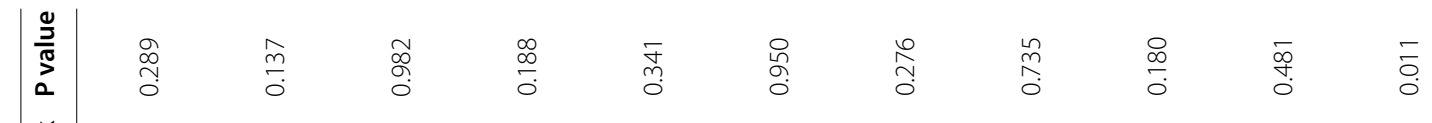

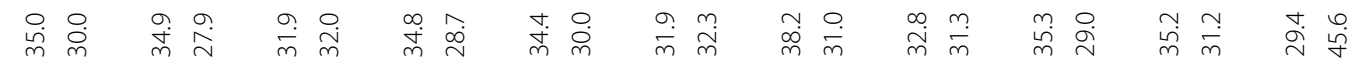

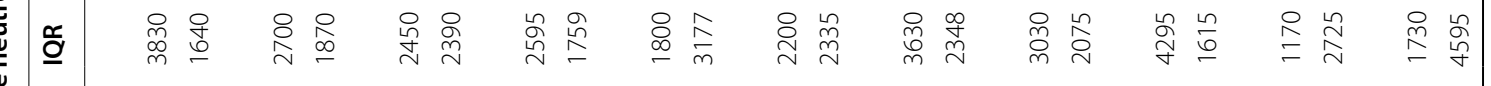
蒙

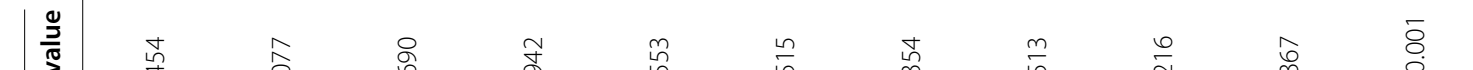

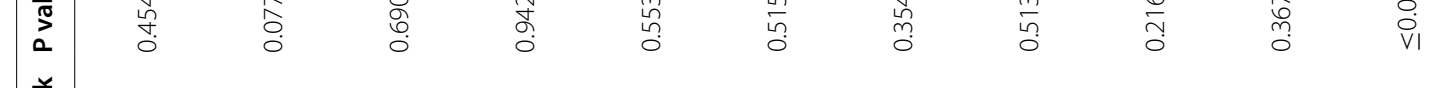

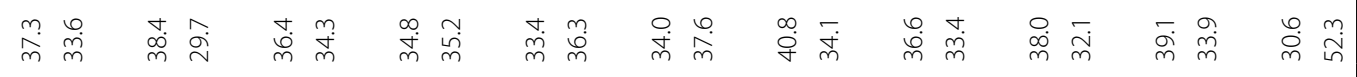

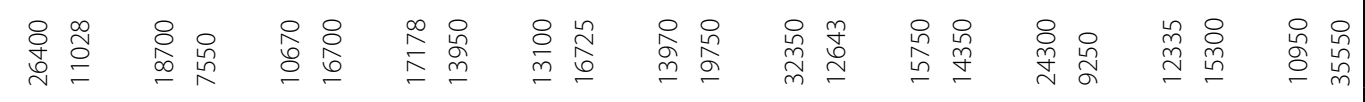

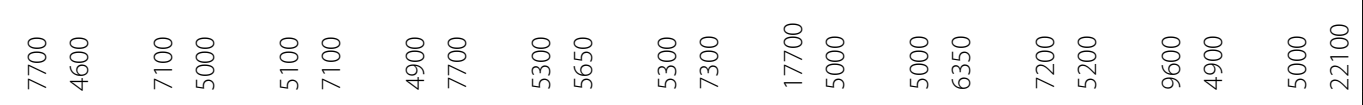

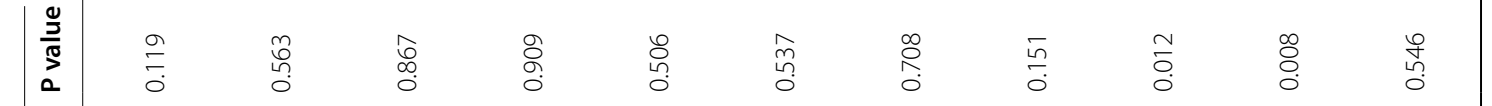

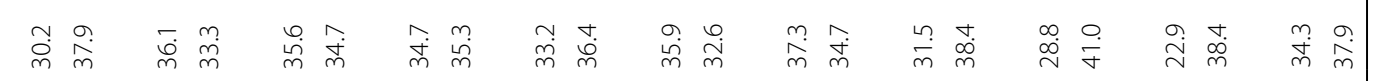

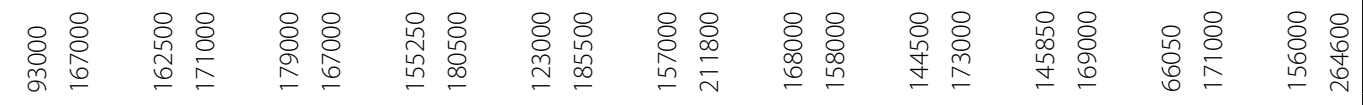

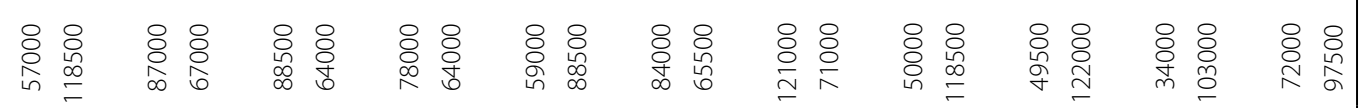

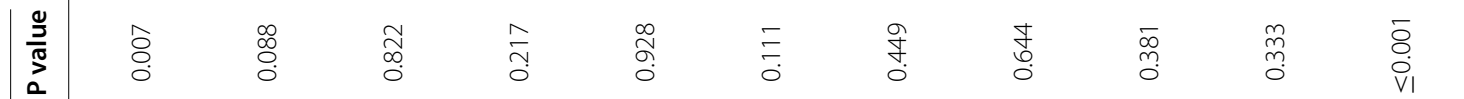

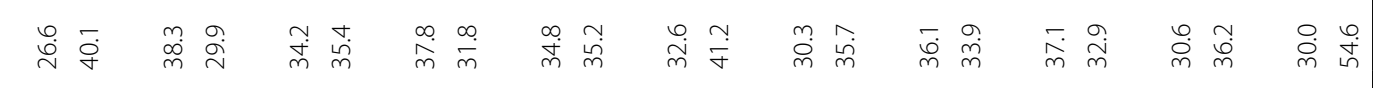

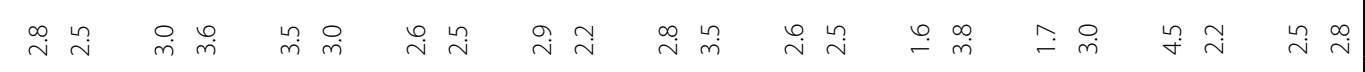

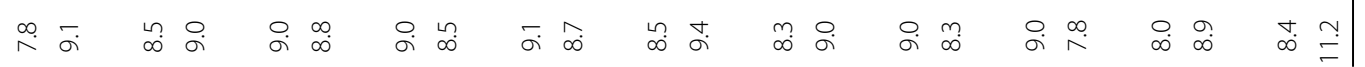

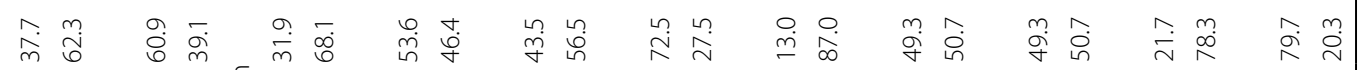
$\stackrel{\sim}{\sim}$ 


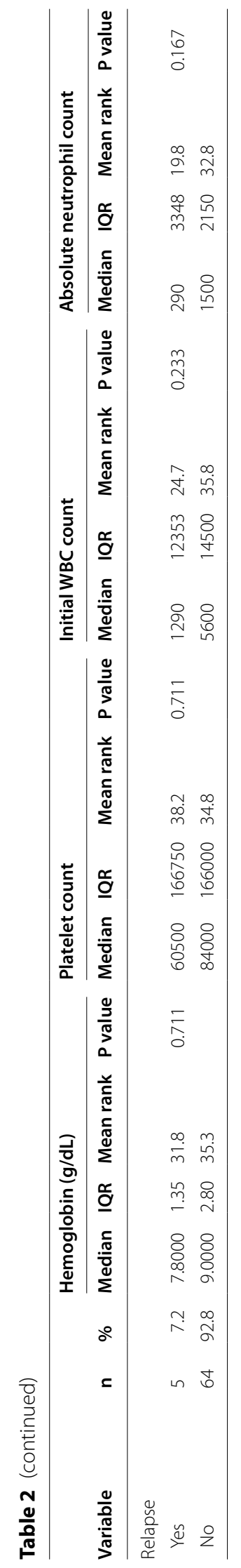




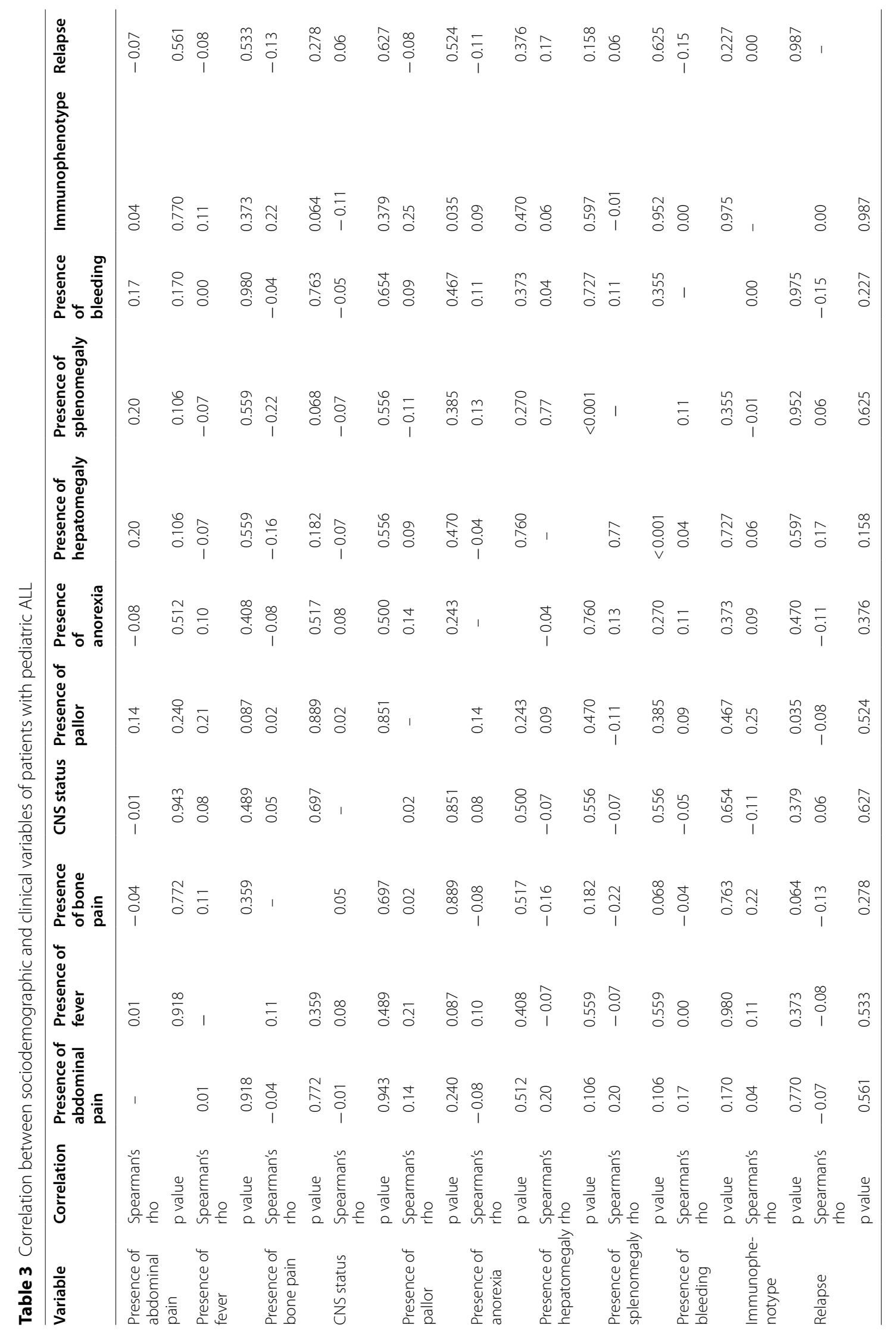


[12]. Hemoglobin levels differed significantly between children older and younger than 5 years and those who had T-ALL or B-ALL. Findings of this study were consistent with those reported in previous studies $[13,14]$. The median platelet count was 80,000 with an IQR of 157000 platelets $/ \mathrm{mm}^{3}$. In a previous larger study in the Middle East, the platelet count was 36,600 platelets $/ \mathrm{mm}^{3}$ [8]. In this study, patients who had splenomegaly and those who had bleeding symptoms had significantly lower platelet count than patients without splenomegaly and bleeding symptoms. Platelet counts after induction chemotherapy could be useful in treatment stratification of patients with pediatric ALL $[15,16]$. Platelet counts could also be used in predicting prognosis and response to chemotherapy $[15,17]$. The median initial WBCs count was 7100 with an IQR of 20,600 cells $/ \mathrm{mm}^{3}$. The median initial WBCs counts were significantly different between patients who had T-ALL and B-ALL. Similarly, the absolute neutrophils counts were also significantly different between patients who had T-ALL and B-ALL. Our findings were consistent with the reported complete blood count and clinical findings of patients with pediatric ALL [13].

Pediatric ALL has many clinical manifestations and patients usually were symptomatic at presentation. Usually, symptoms result from dysfunction of different blood cells. In this study, pallor (72.5\%), fever (53.6\%), bone pain (43.5\%), abdominal pain (31.9\%) and bleeding symptoms $(21.7 \%)$ were the main manifestations at presentation. Our findings showed that pollar was significantly associated with T-ALL. Presence of hepatomegaly was significantly associated with splenomegaly. Manifestations reported in this study were consistent with those reported in larger studies in the Middle East where fever (75.5\%), bone pain (39.6\%), and bleeding symptoms (30.8\%) were the most frequent manifestations of pediatric ALL [8]. In Saudi Arabia, patients presented with fever (70\%), bleeding symptoms (18\%), and bone pain (10\%) [10]. In this study, splenomegaly was reported in $49.3 \%$ of the patients. Al-Mulla et al. reported that $60.8 \%$ of patients with pediatric ALL had splenomegaly [8]. Among Saudi Arabians with pediatric ALL, 42\% of the patients had splenomegaly [10]. Hepatomegaly was present in $49.3 \%$ of the patients with pediatric ALL included in this study. Findings of this study were consistent with those reported in the region among Arab populations in the Middle East and Saudi Arabia as well as those reported among Brazilians [8, 10, 12].

Consistent with international and regional studies, $79.7 \%$ of the patients had B-ALL and $20.3 \%$ of the patients had T-ALL. Findings of this study mirrored those reported in international studies as well as those reported in the Middle East and the region. B-ALL was prevalent in $85 \%$ of Middle Eastern patients with ALL [8],
$82 \%$ of Saudi Arabian patients [10], and $89.5 \%$ of Brazilian patients [12]. Findings of this study reported that the vast majority of the patients (95.7\%) had CNS status 1. Previous studies have shown that CNS infiltration altered protein profiling of the CSF [18]. Our findings were consistent with those reported among Middle Eastern, Saudi Arabian, Moroccan, and Brazilian patients with pediatric ALL $[8,10,12,19]$.

Although cytogenetic studies were not conducted for all patients, the findings of this study were consistent with those reported for the hyperdiploidy, $t(12,21)$, $t(1,19)$, and $t(9,22)$ translocations among patients with pediatric ALL. For example, in a study conducted in King Hussein Center in Jordan reported that about $12 \%$ of the patients with pediatric ALL were positive for translocation $(12,21), 1.7 \%$ were positive for translocation (1, $19)$, and $7.4 \%$ were positive for translocation $(9,22)[11]$. Among Middle Eastern patients with pediatric ALL, 5.1\% had $(9,22)$ translocation [8].

After induction chemotherapy, the vast majority (98.5\%) of the patients included in this study had complete remission. In a larger Middle Eastern study, the remission rate was as high as $96.6 \%$ [8]. In Jordan, the remission rate was $7 \%$ [11]. In this study, $7.2 \%$ of the patients who showed complete remission developed relapse. Relapse rates after complete remission showed variability in previously reported studies in Jordan (9\%) and Pakistan (20\%) [11, 20].

\section{Limitations}

First, this study was based on data collected from the medical record of the patients. Although a data collection form was specifically designed for this study and field researchers had access to the records as many times as they needed, the data collected could be biased by incorrectly entered information in the medical records. Second, this was a single-center study. Although An-Najah National Hospital has emerged as the main referral center for patients with leukemia, including those with pediatric ALL in the West Bank and Gaza Strip, the inclusion of other centers could have permitted a complete description of patients with pediatric ALL in Palestine. Third, the sample size included in this study was relatively small. This could be attributed to the fact that care for patients with cancer is based on fragmentation and patients often receive healthcare outside Palestine.

\section{Abbreviations}

ALL: Acute lymphoblastic leukemia; B-ALL: B-cell precursor immunophenotype-acute lymphoblastic leukemia; CNS: Central nervous system; IQR: Interquartile range; IRB: Institutional review board; MECCA: Middle east childhood cancer alliance; T-ALL: T-cell precursor immunophenotype-acute lymphoblastic leukemia; WBC: White blood cell; WHO: World health organization. 


\section{Acknowledgements}

Authors would like to thank the patients who participated in the study. AnNajah National University is acknowledged for making this study possible.

\section{Authors' contributions}

RS and SM were involved in the conception and design of the work, analysis and interpretation of data, drafting and final approval the manuscript. $\mathrm{YO}, \mathrm{RH}$ and MA were involved in the data acquisition, analysis, drafting the work and final approval of the version to be published. All authors read and approved the final manuscript.

\section{Authors Information}

Ramzi Shawahna, Associate Professor, Department of Physiology, Pharmacology and Toxicology, Faculty of Medicine and Health Sciences, An-Najah National University, Nablus, Palestine, An-Najah BioSciences Unit, Centre for Poisons Control, Chemical and Biological Analyses, An-Najah National University, Nablus, Palestine. Sultan Mosleh is an Assistant Professor, Department of Medicine, Faculty of Medicine and Health Sciences, An-Najah National University, Nablus, Palestine, An-Najah National University Hospital, An-Najah National University, Nablus, Palestine. Yahya Odeh, Rami Halawa, and Majd AlGhoul are Doctor of Medicine candidates, Department of Medicine, Faculty of Medicine and Health Sciences, An-Najah National University, Nablus, Palestine.

\section{Funding}

This study did not receive any specific funding.

\section{Availability of data and materials}

The datasets used and/or analyzed during the current study are available from the corresponding author on reasonable request.

\section{Declarations}

\section{Ethics approval and consent to participate}

The protocol and ethics of this study were approved by the Institutional Review Board (IRB) of An-Najah National University under the Archived Number (IRB-20-2017). Approval was also obtained from the hospital administration to access the patient information. Data and information leading to the identity of the patient were not collected into the data collection form. The data were coded during the data analysis.

\section{Consent for publication}

Not applicable.

\section{Competing interests}

All authors declare that they have no competing interest.

\section{Author details}

1Department of Physiology, Pharmacology and Toxicology, Faculty of Medicine and Health Sciences, An-Najah National University, New Campus, Building: 19, Office: 1340, P.O. Box 7, Nablus, Palestine. ${ }^{2}$ An-Najah BioSciences Unit, Centre for Poisons Control, Chemical and Biological Analyses, An-Najah National University, Nablus, Palestine. ${ }^{3}$ Department of Medicine, Faculty of Medicine and Health Sciences, An-Najah National University, Nablus, Palestine. ${ }^{4}$ An-Najah National University Hospital, An-Najah National University, Nablus, Palestine.

Received: 6 March 2021 Accepted: 29 June 2021

Published online: 05 July 2021

\section{References}

1. Kharroubi AT, Seir R. Cancer care in palestine. In: Cancer care in countries and societies in transition. Berlin: Springer; 2016. p. 77-97.

2. Halahleh K, Gale RP. Cancer care in the palestinian territories. Lancet Oncol. 2018;19(7):e359-64.

3. Smith MA, Seibel NL, Altekruse SF, Ries LA, Melbert DL, O'Leary M, Smith FO, Reaman GH. Outcomes for children and adolescents with cancer: challenges for the twenty-first century. J Clin Oncol. 2010;28(15):2625-34.
4. Siegel R, Naishadham D, Jemal A. Cancer statistics, 2014. CA Cancer J Clin. 2012;62(1):10-29.

5. Inaba H, Greaves M, Mullighan CG. Acute lymphoblastic leukaemia. Lancet. 2013;381(9881):1943-55

6. Bailony MR, Hararah MK, Salhab AR, Ghannam I, Abdeen Z, Ghannam J. Cancer registration and healthcare access in West Bank, Palestine: a GIS analysis of childhood cancer, 1998-2007. Int J Cancer. 2011;129(5):1180-9.

7. Rivera-Luna R, Shalkow-Klincovstein J, Velasco-Hidalgo L, CárdenasCardós R, Zapata-Tarrés M, Olaya-Vargas A, Aguilar-Ortiz MR, AltamiranoAlvarez E, Correa-Gonzalez C, Sánchez-Zubieta F, et al. Descriptive epidemiology in Mexican children with cancer under an open national public health insurance program. BMC Cancer. 2014;14:790.

8. Al-Mulla NA, Chandra P, Khattab M, Madanat F, Vossough P, Torfa E, Al-Lamki Z, Zain G, Muwakkit S, Mahmoud S, et al. Childhood acute lymphoblastic leukemia in the Middle East and neighboring countries: a prospective multi-institutional international collaborative study (CALLME1) by the middle east childhood cancer alliance (MECCA). Pediatr Blood Cancer. 2014;61(8):1403-10.

9. Abuhelwa Z, Al Shaer Q, Taha S, Ayoub K, Amer R. Characteristics of de novo acute myeloid leukemia patients in Palestine: experience of An-Najah National University Hospital. Asian Pac J Cancer prev. 2017;18(9):2459-64.

10. Al Omari A, Hussein T, Albarrak K, Habib A, Sambas A, Sheblaq N, Omair A. Clinical characteristics and outcomes of acute lymphoblastic leukaemia in children treated at a single tertiary hospital in Riyadh Saudi Arabia. J Health Spec. 2018;6(1):14-8.

11. Halalsheh $H$, Abuirmeileh N, Rihani R, Bazzeh F, Zaru L, Madanat F. Outcome of childhood acute lymphoblastic leukemia in Jordan. Pediatr Blood Cancer. 2011;57(3):385-91.

12. Lustosa DW, de Sousa F, de Almeida V, Ferreira FH, Félix C, de Oliveira Lopes MV. Acute lymphoblastic leukemia in children and adolescents prognostic factors and analysis of survival. Revista Brasileira de Hematologia e Hemoterapia. 2015;37(4):223-9.

13. Jaime-Pérez JC, García-Arellano G, Herrera-Garza JL, Marfil-Rivera LJ, Gómez-Almaguer D. Revisiting the complete blood count and clinical findings at diagnosis of childhood acute lymphoblastic leukemia: 10-year experience at a single center. Hematol Transfus Cell Ther. 2019;41(1):57-61.

14. Teuffel O, Stanulla M, Cario G, Ludwig WD, Rottgers S, Schafer BW, Zimmermann M, Schrappe M, Niggli FK. Anemia and survival in childhood acute lymphoblastic leukemia. Haematologica. 2008;93(11):1652-7.

15. Zeidler L, Zimmermann M, Möricke A, Meissner B, Bartels D, Tschan C, Schrauder A, Cario G, Goudeva L, Jäger S, et al. Low platelet counts after induction therapy for childhood acute lymphoblastic leukemia are strongly associated with poor early response to treatment as measured by minimal residual disease and are prognostic for treatment outcome. Haematologica. 2012;97(3):402-9.

16. Grunnan JD, Rosthøj S. Time course of peripheral blood count recovery during induction chemotherapy for childhood acute lymphoblastic leukemia. Hematology. 2019;24(1):467-72.

17. Yan A, Erdman L, Sung L, Bernstein S. Teetering on a liver's edge: a case report highlighting clinical decision-making in thrombocytopenia. BMC Cancer. 2019;19(1):1058

18. Mo F, Ma X, Liu X, Zhou R, Zhao Y, Zhou H. Altered CSF proteomic profiling of Paediatric acute lymphocytic leukemia patients with CNS infiltration. J Oncol. 2019;2019:3283629.

19. Bachir F, Bennani S, Lahjouji A, Cherkaoui S, Harif Mh, Khattab M, Nassereddine I, Zafad S, El Aouad R. Characterization of acute lymphoblastic leukemia subtypes in Moroccan children. I J Pediatr. 2009;2009:674801.

20. Siddiqui EU, Kazi SG, Habib MI, Ahmed Khan KM, Zia N. Pattern of relapse in paediatric acute lymphoblastic leukaemia in a tertiary care unit. JPMA. 2016;66(8):961-7.

\section{Publisher's Note}

Springer Nature remains neutral with regard to jurisdictional claims in published maps and institutional affiliations. 